\title{
Pengaruh Faktor Ekternal dan Internal terhadap Minat Mahasiswa Memilih Karir sebagai Wirausaha
}

\author{
KUKUH MULYANTO \\ STIE Anindyaguna \\ Jl. Tentara Pelajar 49 Semarang \\ Email : Kukuh@stieanindyaguna.ac.id
}

\section{Diterima 13 Agustus 2021; disetujui 26 Agustus 2021;}

\begin{abstract}
This study aims to determine the effect of external and internal factors on intention students to entrepreneur career. The population used in this study were student in STIE Anindyaguna and STTPati which amounts to 100 people. Method of sampling technique in this study carried with purposive sampling. The analysis tool used is the technique of path analysis. The results obtained in this study is the positive effect of external and internal factors on intention students to entrepreneur career.
\end{abstract}

Keywords : External Factor, Internal Factor, Intention Entrepreneur

\section{PENDAHULUAN}

Pendidikan kewirausahaan sekarang ini mulai mendapat perhatian yang serius dari akademisi maupun para pembuat kebijakan. Sejak pertama kali diberikan pada tahun 1947 di Harvard Business School, kuliah kewirausahaan mulai diadopsi oleh banyak universitas dengan memasukkannya ke dalam kurikulum mereka (Manea et al 2019). Hal ini kemungkinan disebabkan oleh kesadaran bahwa pendidikan kewirausahaan memiliki kontribusi pada pertumbuhan ekonomi (Acs, 2016).

Pendidikan kewirausahaan dapat mewujudkan potensi kewirausahaan, seperti: membantu mengembangkan kemampuan melihat peluang bisnis, membantu meningkatkan keterampilan dalam mempersiapkan pekerjaan, dan meningkatkan kemampuan untuk mengambil tanggung jawab (Manea et al 2019) maka pendidikan kewirausahaan sering dianggap sebagai faktor penting dalam mendorong aktivitas kewirausahaan (Negoescu, 2013).

Oleh karena itu Filip, (2017) berpendapat bahwa mengajarkan kewirausahaan adalah suatu keniscayaan.
Meskipun bukan berarti bahwa pendidikan kewirausahaan akan dapat mengurangi kesulitan yang akan dihadapi wirausaha saat mereka menjalankan bisnisnya. Akan tetapi setidaknya wirausaha yang memiliki pendidikan yang tinggi akan terus menerus mencari cara untuk mengembangkan bisnis, dan cara menghadapi kesulitan baru yang perlu dipecahkan (Avram \& Sabou (2016)

Di kampus, pendidikan kewirausahaan miliki tujuan untuk menanamkan pada mahasiswa sikap, pengetahuan dan keterampilan untuk bertindak secara kewirausahaan (Tsakiridou \& Stergiou, 2014), serta mendorong kreativitas dan inovasi (Medar, 2015). Bagaimanapun mengembangkan kompetensi kewirausahaan ini membutuhkan lingkungan pendidikan yang mendorong mahasiswa pada penemuan dan kreativitas, memungkinkan mereka mengambil risiko dan membuat kesalahan, yang harus dipandang sebagai kesempatan belajar (Moberg, 2014).

Menurut catatan Susilosingsih (2015) sejak tahun 1997 Dikti sebenarnya telah memfasilitasi pendidikan kewirausahaan di perguruan tinggi dengan mengadakan program pengembangan kewirausahaan 
yang menawarkan berbagai kegiatan yang terkait dengan kewiraushaaan, yaitu: Kuliah Kewirausahaan (KWU), Magang Kewirausahaan (MKU), Kuliah Kerja Usaha (KKU), Konsultasi Bisnis dan Penempatan Kerja (KBPK), dan Inkubator Wirausaha Baru (INWUB). Disamping itu Dikti juga menawarkan program yang dikemas sebagai program kreativitas mahasiswa (PKM) yang memfasilitasi mahasiswa untuk berkreasi dalam bidang kewirausahaan. Dikti, sejak tahun 2009, juga menyediakan skim bagi mahasiswa yang berminat sebagai job creator melalui program mahasiswa wirausaha (PMW). Hal ini sejalan dengan Peraturan Pemerintah Nomor 17 tahun 2010 yang menyatakan bahwa tujuan pendidikan tinggi antara lain adalah membentuk insan yang kritis, kreatif, inovatif, mandiri, percaya diri dan berjiwa wirausaha.

Namun demikian masih belum diketahui dengan jelas hubungan antara pendidikan kewirausahaan dengan keputusan untuk berkarir di dunia kewirusahaan. Meskipun banyak penelitian (seperti: Kumar et al 2013) yang menunjukkan pengaruh positif yang signifikan dari pendidikan kewairausahaan terhadap minat memilih karir sebagai wirausaha, akan tetapi beberapa penelitian (Oosterbeek et al. 2010) yang menunjukkan bahwa pendidikan kewirausahaan memiliki pengaruh negatif terhadap minat memilih karir sebagai wirausaha.

Faktor dukungan keluarga juga sering dianggap sebagai faktor yang mempengaruhi minat mahasiswa untuk menjadi wirausaha. Akan tetapi hasil penelitian mengenai hal inipun menunjukkan hasil yang tidak konsisten. Rahmadi dan Heryanto (2016) justru menunjukkan bahwa lingkungan keluarga tidak memiliki pengaruh yang signifikan pada Mahasiswa.

Dengan demikian penelitian mengenai pengaruh pendidikan kewirausahaan terhadap mahasiswa masih sangat relevan untuk dilakukan. Dalam penelitian ini digunakan pendekatan dari Carlsson et al. (2013) yang menggunakan faktor eksternal dan internal untuk melihat determinan minat seseorang pada kewirausahaan. Hal ini mengingat bahwa beberapa literature penelitian terdahulu nampak bahwa minat mahasiswa terhadap kewirausahaan bergantung pada faktor eksternal dan internal individu (Manea et al., 2019).

Penelitian yang membahas masalah kewirausahaan tentunya sangat penting bagi perguruan tinggi, karena dapat diharapkan menjadi dasar dalam membuat model kurikulum untuk pengembangan dan peningkatan keterampilan kewirausahaan mahasiswa

Berdasarkan latar belakang tersebut maka permasalahan dalam penelitian ini adalah bagaimana kompetensi kewirausahaan, persepsi terhadap pendidikan kewirausahaan dan dukungan keluarga terhadap minat menjadi wirausaha. Tujuan penelitian ini adalah untuk mengetahui pengaruh kompetensi kewirausahaan, persepsi terhadap pendidikan kewirausahaan dan dukungan keluarga terhadap minat menjadi wirausaha

\section{TINJAUAN TEORETIS}

Kewirausahaan. Jika mengacu pada Drucker maka kewirausahaan atau entrepreneur dapat diartikan sebagai merubah sumber-sumber ekonomi dari area yang produktivitasnya dan hasilnya rendah menuju area dengan produktivitas yang lebih tinggi dan dengan hasil yang lebih besar (Drucker, 2007). Kewirausahaan merupakan suatu ciri yang dapat diamati dalam tindakan seseorang atau institusi. Tidak hanya terdapat dalam bidang bisnis, akan tetapi wirausaha juga terdapat dalam bidang-bidang seperti: kesehatan, pendidikan dan bisnis pada dasarnya bekerja dengan cara yang sama, mereka bekerja lebih baik, mereka melakukannya berbeda dari yang lain (Drucker, 2007).

Merujuk pendapat Drucker, maka seseorang dapat dikategorikan sebagai wirausaha atau bukan, itu dapat diamati dari tindakan orang tersebut. Seseorang yang selalu bekerja dengan lebih baik dan berbeda dari yang lain, apapun bidang 
pekerjaannya, maka orang itu dapat disebut wirausaha, (Drucker, 2007). Hal yang sama juga dinyatakan Hisrich \& Peters (1992) wirausaha adalah inovator oleh karena itu kewirausahaan meliputi serangkaian perilaku, keterampilan dan sifat yang mendukung pengembangan inovasi dan kreativitas.

Schumpeter (1934 dalam de Klerk \& Kruger, 2002) juga berpendapat bahwa wirausaha adalah seseorang yang berhubungan dengan kegiatan creative destruction, sebab wirausaha secara terus menerus mengembangkan metode yang ada dan produk-produk lama melalui pengenalan inovasi-inovasi baru (Morris, Lewis \& Sexton, 1994). Dengan demikian ini berarti bahwa seseorang tidak dapat dikatakan sebagai wirausaha apabila tidak inovatif, tidak mampu melakukan perubahan, 'merusak' kondisi yang sudah ada secara kreatif (perubahan konstruktif) agar menjadi lebih baik, memiliki nilai yang lebih besar dari sebelumnya.

Secara umum kewirausahaan dapat diartikan sebagai identifikasi dan eksploitasi peluang yang tidak biasa dan kreatif yang sistematis untuk penciptaan nilai, di mana hasil nilai yang diinginkan dapat bersifat komersial, sosial, kelembagaan, atau budaya (Iazzolino et al., 2019).

Menurut European Commission (2018) kewirausahaan dapat diartikan sebagai: "kewirausahaan adalah kemampuan untuk mengubah ide menjadi tindakan. Ini melibatkan kreativitas, inovasi dan pengambilan risiko, serta kemampuan untuk merencanakan dan mengelola proyek untuk mencapai tujuan. Individu menyadari konteks pekerjaannya dan mampu menangkap peluang yang muncul. Ini adalah dasar untuk memperoleh keterampilan dan pengetahuan yang lebih spesifik yang dibutuhkan oleh mereka yang membangun atau berkontribusi pada aktivitas sosial atau komersial. Ini harus mencakup kesadaran akan nilai-nilai etika dan promosi tata pemerintahan yang baik."

Stewart et al.(1998) menyatakan bahwa tumbuhnya minat berwirausaha dipengaruhi oleh berbagai faktor, yang melibatkan berbagai faktor internal, faktor eksternal dan faktor kontekstual.

Faktor eksternal. Faktor eksternal adalah institusi, seperti konteks universitas, pengalaman bisnis keluarga dan konteks sosial ekonomi. Keadaan ini dapat mendorong berkembangnya pengetahuan yang dibutuhkan untuk memulai usaha dan membiasakan mahasiswa dengan dunia wirausaha. Sastra menunjukkan hubungan yang jelas antara kemauan siswa untuk menjalankan bisnis dan kemungkinan mengakses pengetahuan yang diperlukan untuk menjalankan bisnis (Bergmann et al., 2018; Fiet, 2001; Filip, 2017; Negoescu, 2013).

Faktor internal yang berasal dari dalam diri wirausaha dapat berupa sifat-sifat personal, persepsi, kemauan dan kemampuan individu yang dapat memberi kekuatan individu untuk berwirausaha. Faktor eksternal berasal dari luar diri wirausaha yang dapat berupa unsur dari lingkungan sekitar seperti lingkungan keluarga, lingkungan dunia usaha, lingkungan fisik, lingkungan sosial ekonomi dan lain-lain. Suryana (2008) juga menyatakan bahwa faktor yang berasal dari lingkungan di antaranya adalah model peran, peluang, aktivitas, selain itu dipengaruhi juga oleh pesaing, sumber daya, dan kebijakan pemerintah. Tjahjono dan Ardi (2008) juga menjelaskan bahwa bagi banyak orang keputusan untuk berwirausaha merupakan perilaku dengan keterlibatan yang akan melibatkan: 1. Faktor internal (kepribadian, persepsi, motivasi dan pembelajaran (sikap) dan 2. Faktor eksternal (lingkungan keluarga, teman dan tetangga). David C McClelland (dalam Suryana 2008) menyatakan bahwa kewirausahaan ditentukan oleh motif berprestasi, optimisme, sikap nilai, dan status kewirausahaan atau keberhasilan.

Faktor internal. Faktor internal adalah sikap kewirausahaan mahasiswa dan ketegasan. Keinginan untuk memulai bisnis yang dimotivasi oleh hasrat pribadi, yang dapat berasal dari pengalaman masa lalu dan 
kemampuan pribadi. Semua faktor tersebut mempengaruhi proses pengambilan keputusan mahasiswa dalam memutuskan memilih karir menjadi wirausaha (Nicodim et al., 2016).

Kompetensi kewirausahaan. Kompetensi kewirausahaan dapat diartikan sebagai karakteristik tingkat tinggi yang mencakup: ciri-ciri kepribadian, keterampilan, dan pengetahuan yang menghasilkan kemampuan untuk mencapai sesuatu melalui penggunaan sumber daya (Rasmussen et al., 2011). Oleh karena itu hipotesis yang diajukan dalam penelitian ini adalah:

H1 : Kompetensi kewirausahaan berpengaruh positif minat menjadi minat mahasiswa untuk berwirausaha.

Pendidikan kewirausahaan. Persepsi terhadap pendidikan kewirausahaan dapat diartikan sebagai persepsi terhadap kegiatan belajar mengajar tentang kewirausahaan yang melibatkan pengembangan pengetahuan, keterampilan, sikap dan kualitas pribadi yang sesuai dengan usia dan perkembangan mahasiswa (Lin et al., 2008). Pada dasarnya pendidikan kewirausahaan bertujuan untuk meningkatkan kesadaran berwirausaha sebagai pilihan karir (Arasti et al., 2012).

Lembaga pendidikan memainkan peran penting dalam membentuk minat siswa untuk berwirausaha melalui upaya dosen untuk mendorong mahasiswa untuk terjun ke dunia kewirausahaan serta melalui penyelenggaraan seminar kewirausahaan untuk mahasiswa (Manea et al 2019). Dalam penelitian Manea et al (2019), ditunjukkan bahwa persepsi terhadap pendidikan kewirausahaan mempengaruhi kemauan mahasiswa untuk menjadi wirausaha. Hasil penelitian ini sesuai dengan hasil penelitian dari Kumar et al. (2012).

Banyak mahasiswa yang tertarik pada informasi tentang masalah kewirausahaan (Manea et al 2019). Oleh karena itu, untuk menarik minat siswa pada karir wirausaha maka kampus seharusnya lebih banyak membahas aspek kewirausahaan dalam pelatihan maupun seminar. Meningkatnya minat terhadap informasi kewirausahaan ini sejalan dengan hasil penelitian yang dilakukan oleh Sumedrea (2017) yang menyatakan bahwa mahasiswa menyatakan minat yang meningkat untuk mengikuti pertemuan-pertemuan yang akan datang terkait dengan kewirausahaan. Oleh karena itu hipotesis yang diajukan dalam penelitian ini adalah:

H2 : Persepsi terhadap pendidikan kewirausahaan berpengaruh positif terhadap minat menjadi wirausaha.

Dukungan Keluarga. Mahasiswa termotivasi dan memiliki kemauan yang tinggi untuk menjadi wirausaha, karena keluarga serta teman-teman mereka yang mendukung dalam pilihan karir ini (Manea et al 2019). Hasil penelitian ini konsisten dengan makalah Kumar et al. (2013).

Simpulan yang sama juga diperoleh penelitian yang dilakukan oleh Yusuf, dkk (2017) yang menemukan adanya pengaruh yang signifikan lingkungan keluarga terhadap minat berwirausaha mahasiswa

Oleh karena itu hipotesis yang diajukan dalam penelitian ini adalah:

H3 : Dukungan keluarga berpengaruh positif terhadap minat menjadi wirausaha

\section{METODE PENELITIAN}

Penelitian ini merupakan explanatory research dengan pendekatan kuantitatif dengan metode survei. Responden penelitian ini adalah mahasiswa STIE Anindyaguna dan STTPati.

Teknik sampling yang digunakan adalah puposive sampling, yaitu mereka yang sudah menempuh kuliah kewirausahaan.

Dalam menentukan jumlah sampel yang representative penelitian ini mengacu pada Hair et al. (2010), yaitu bahwa jumlah indikator dikali 5 sampai 10. Oleh karena jumlah sampel dalam penelitian ini adalah: 12 (jumlah indikator) x $5=60 \mathrm{n}$.

Teknik pengumpulan data dalam penelitian ini adalah dengan melakukan pengamatan langsung di lapangan, dengan membagikan kuesioner. 


\section{Gambar 1 \\ Kerangka Pemikiran Teoritis}

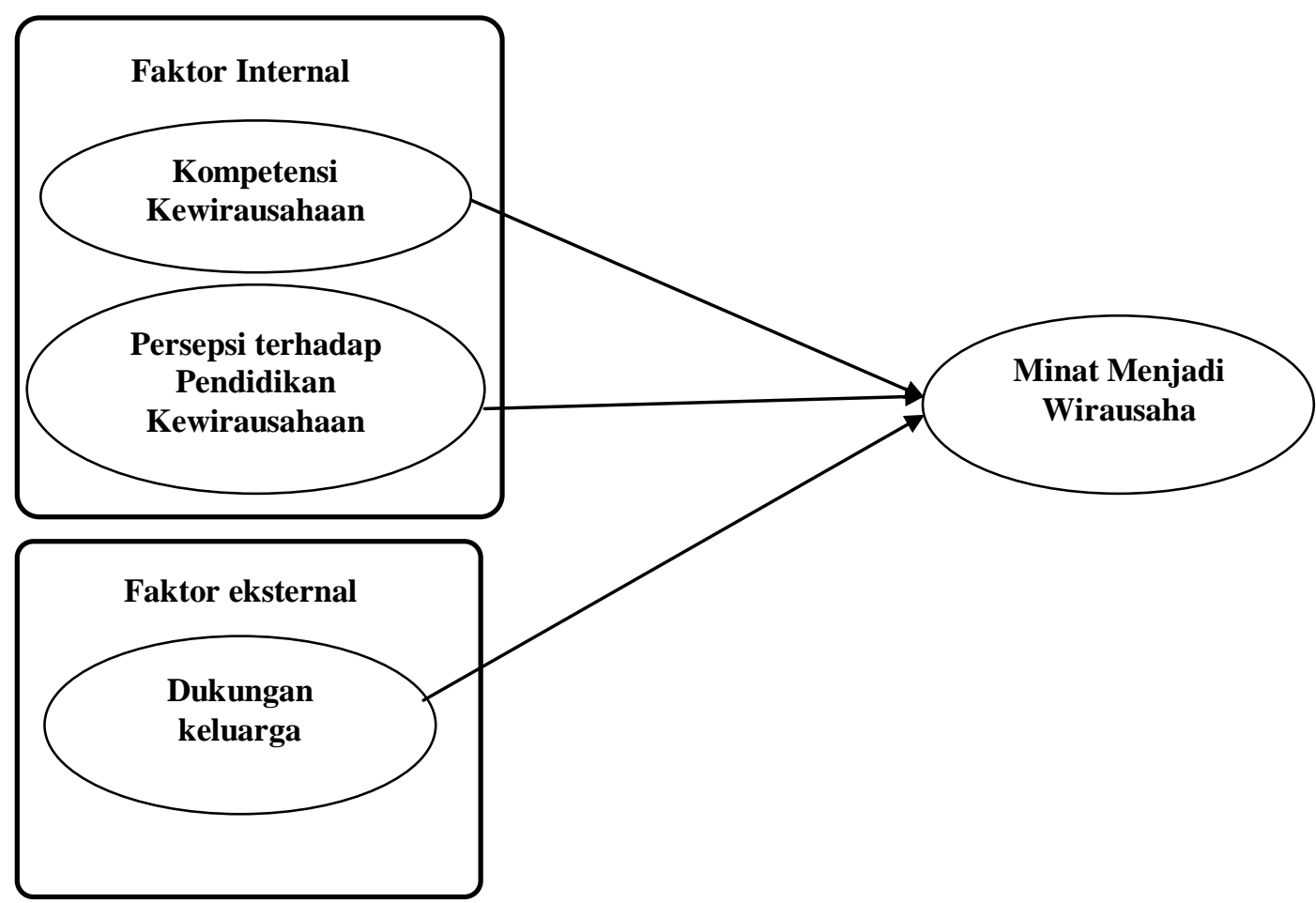

Disamping itu studi pustaka dilakukan dalam rangka mengumpulkan data atau informasi dengan bertujuan untuk menemukan teori, konsep dan variabel lain yang dapat mendukung penelitian. Didalam metode studi pustaka ini, peneliti mencari data melalui referensi-referensi, jurnal dan artikel di internet.

Metode analisis data dalam penelitian ini adalah analisis deskriptif dan analisis statistik inferensial dengan menggunakan analisis regresi linier berganda.

\section{HASIL DAN PEMBAHASAN}

Hasil olah data menunjukkan bahwa korelasi antara masing-masing skor $r$ hitung $>\mathrm{r}$ kritis (tabel). Dengan demikian indikator dinyatakan valid.

Berdasarkan olah data, diperoleh nilai Cronbach's Alpha > 0,6, maka dapat di simpulkan bahwa keempat variabel yaitu kompetensi kewirausahaan, persepsi terhadap pendidikan kewirausahaan, dukungan keluarga dan minat menjadi wirausaha adalah reliabel.

Dari hasil regresi tersebut dapat disimpulkan bahwa :

1. Nilai koefisien regresi kompetensi kewirausahaan $\left(\mathrm{X}_{1}\right)$ adalah sebesar 0,283 . Hal ini menunjukkan bahwa kompetensi kewirusahaan mahasiswa memiliki pengaruh positif pada minat mereka menjadi wirausaha. Artinya bahwa semakin tinggi tingkat kompetensi kewirausahaan mahasiswa, maka akan semakin tinggi pula minat mereka menjadi wirausaha.

2. Nilai koefisien regresi persepsi pendidikan kewirausahaan $\left(\mathrm{X}_{2}\right)$ adalah sebesar 0,308. Hal ini menunjukkan bahwa semakin baik persepsi mahasiswa terhadap pendidikan kewirusahaan memiliki pengaruh positif pada minat mahasiswa menjadi wirausaha. Artinya bahwa semakin baik persepsi mahasiswa terhadap pendidikan kewirausahaan yang diperolehnya, maka akan semakin tinggi 
Tabel 1

Model Summary Out Put Hasil SPSS

\begin{tabular}{lrrrr}
\hline Model & $\mathrm{R}$ & R Square & $\begin{array}{c}\text { Adjusted R } \\
\text { Square }\end{array}$ & $\begin{array}{l}\text { Std. Error of } \\
\text { the Estimate }\end{array}$ \\
\hline 1 & $.678^{\mathrm{a}}$ & .459 & .442 & 3.32826 \\
\hline
\end{tabular}

a. Predictors: (Constant), dukungan keluarga , kompetensi

kewirausahaan, persepsi pendidikan kewirausahaan

Tabel 2

Uji SPSS Regresi Sederhana

Coefficients $^{\mathrm{a}}$

\begin{tabular}{|c|c|c|c|c|c|c|}
\hline \multirow{2}{*}{\multicolumn{2}{|c|}{ Model }} & \multicolumn{2}{|c|}{$\begin{array}{l}\text { Unstandardized } \\
\text { Coefficients }\end{array}$} & \multirow{2}{*}{$\begin{array}{c}\begin{array}{l}\text { Standardized } \\
\text { Coefficients }\end{array} \\
\text { Beta }\end{array}$} & \multirow[t]{2}{*}{$\overline{\mathrm{T}}$} & \multirow[t]{2}{*}{ Sig. } \\
\hline & & $\mathrm{B}$ & Std. Error & & & \\
\hline \multirow[t]{4}{*}{1} & (Constant) & -2.367 & 2.541 & & -.932 & .354 \\
\hline & $\begin{array}{l}\text { KOMPETENSI } \\
\text { KEWIRAUSAHAAN }\end{array}$ & .266 & .072 & .283 & 3.724 & .000 \\
\hline & $\begin{array}{l}\text { PERSEPSI PENDIDIKAN } \\
\text { KEWIRAUSAHAAN }\end{array}$ & .351 & .088 & .308 & 4.003 & .000 \\
\hline & $\begin{array}{l}\text { DUKUNGAN } \\
\text { KELUARGA }\end{array}$ & .554 & .099 & .434 & 5.572 & .000 \\
\hline
\end{tabular}

a. Dependent Variable: MINAT MENJADI WIRAUSAHA

minat mahasiswa menjadi wirausaha.

3. Nilai koefisien regresi dukungan keluarga $\left(\mathrm{X}_{3}\right)$ adalah sebesar 0,434. Hal ini menunjukkan bahwa dukungan keluarga memiliki pengaruh positif pada minat mereka menjadi wirausaha. Artinya bahwa semakin tinggi dukungan keluarga, maka akan semakin tinggi minat mereka menjadi wirausaha

Dari hasil perhitungan $F$ hitung $(13,15)>$ F-tabel $(3,15)$ dan signifikansi. Dengan demikian Ho ditolak dan $\mathrm{Ha}$ diterima, maka dapat disimpulkan kelayakan model penelitian yang meneliti pengaruh antara kompetensi kewirausahaan, pendidikan kewirausahaan, dan dukungan keluarga terhadap minat mahasiswa menjadi wirausaha adalah baik.

Nilai koefisien determinasi adalah sebesar 0,442 yang berarti variasi perubahan minat menjadi wirausaha (Y) kompetensi wirausaha $\left(\mathrm{X}_{1}\right)$, pendidikan kewirausahaan $\left(\mathrm{X}_{2}\right)$ dan dukungan keluarga $\left(\mathrm{X}_{3}\right)$ sebesar $44,2 \%$ sedangkan sisanya $55,8 \%$ dipengaruhi oleh faktor lain.

Tujuan penelitian ini adalah meneliti pengaruh kompetensi kewirausahaan, pendidikan kewirausahaan serta dukungan keluarga terhadap minat mahasiswa menjadi wirausaha. Hasil penelitian menunjukkan beberapa hal yang dijelaskan sebagai berikut:

1. Hasil penelitian menunjukkan bahwa kompetensi kewirausahaan memiliki pengaruh positif dan signifikan pada minat mahasiswa untuk memilih jalur menjadi wirausaha. Sebagian mahasiswa yang memiliki ketrampilan dalam menemukan peluang bisnis, mampu melakukan presentasi penjualan memiliki minat menjadi wirausaha. Meskipun dalam mata kuliah kewirausahaan mereka mendapat tugas untuk menciptakan bisnis awal, akan tetapi mahasiswa yang kurang kompeten dalam bidang bisnis memiliki kecenderungan untuk tidak bersungguh- 
sungguh dalam mata kuliah ini karena memang dirinya tidak berminat untuk menjadi wirausaha.

2. Hasil penelitian menunjukkan bahwa persepsi pendidikan memiliki pengaruh positif dan signifikan pada minat mahasiswa untuk memilih jalur menjadi wirausaha. Pengetahuan yang diperoleh mahasiswa tentang bisnis dan kewirausahaan dalam mata kuliah kewirausahaan ternyata memiliki pengaruh terhadap minat mereka terhadap pilihan karir menjadi wirausaha. Oleh karena itu wajar jika Rasmussen \& Borch, (2010) dalam penelitiannya juga menyatakan bahwa untuk menumbuhkan minat kewirausahaan mahasiswa maka perguruan tinggi seharusnya menerapkan langkah-langkah untuk meningkatkan iklim kewirausahaannya seperti, mengadakan seminar, pelatihan, workshop, terkait dengan kewirausahaan.

3. Hasil penelitian menunjukkan bahwa faktor dukungan keluarga memiliki pengaruh positif dan signifikan pada minat mahasiswa untuk memilih jalur menjadi wirausaha. Mahasiswa yang memang berasal dari keluarga pebisnis pada umumnya cenderung mendapatkan dukungan dari pihak keluarga sehingga hal ini membuat mereka lebih memilih untuk menjadi wirausaha daripada menjadi karyawan.

Temuan ini sesuai dengan hasil penelitian dari Manea et al (2019) yang menunjukkan bahwa mahasiswa termotivasi dan memiliki kemauan yang tinggi untuk menjadi wirausaha, karena keluarga serta teman-teman mereka mendukung dalam pilihan ini. Hasil penelitian ini konsisten juga dengan makalah Kumar et al. (2013). Dan Yusuf, dkk (2017) yang menemukan adanya pengaruh yang signifikan lingkungan keluarga terhadap minat berwirausaha mahasiswa.

\section{SIMPULAN}

Simpulan dari penelitian ini adalah:

1. Kompetensi kewirausahaan memiliki pengaruh positif dan signifikan pada minat mahasiswa untuk menjadi wirausaha

2. Persepsi terhadap pendidikan kewirausahaan memiliki pengaruh yang signifikan pada minat mahasiswa untuk menjadi wirausaha

3. Faktor dukungan keluarga memiliki pengaruh positif dan signifikan pada minat menjadi wirausaha

Saran. Berdasarkan kesimpulan di atas, maka saran yang diajukan sebagai berikut:

1. Pengetahuan tentang dunia kewirausahaan yang diperoleh mahasiswa memiliki pengaruh pada minat mereka untuk menjadi wirausaha, dan tentunya juga akan diterapkan mahasiswa saat mereka membangun dan menjalankan bisnis. Oleh karena itu, perguruan tinggi hendaknya memenuhi mata kuliah kewirausahaan dengan informasi yang berorientasi masa depan, positif dan proaktif, yang sangat berharga bagi para calon wirausahawan muda.

2. Perguruan tinggi seharusnya juga mendorong keluarga mahasiswa agar memotivasi putra putri mereka untuk meningkatkan ketrampilan kewirausahaan mahasiswa.

3. Peneliti mendatang diharapkan melanjutkan penelitian ini dengan mengeksplorasi kemungkinan variabel lain yang dapat mempengaruhi minat kewirausahaan mahasiswa.

\section{DAFTAR PUSTAKA}

Acs, Z.J. (2016) "How Is Entrepreneurship Good for Economic Growth?", Innovation, no. 2: $97-107$

Acs, Z.J., \& Audretsch, D.B. (2003) Handbook of entrepreneurship research: An interdisciplinary survey and introduction. Boston: Kluwer Academic Publishers

Arasti, Z., Falavarjani, M.K. \& Imanipour, N. (2012) "A study of teaching methods in 
entrepreneurship education for graduates' students", Higher Education Studies, vol. 2, no. 1: $2-10$

Bergmann, H., Geissler, M., Hundt, C., \& Grave, B. (2018) "The climate for entrepreneurship at higher education institutions", Research Policy, vol. 47, no. 4: 700-716

Burton, M.D., Sorensen, J.B., \& Dobrev, S.D. (2016) "A careers perspective on entrepreneurship", Entrepreneurship: Theory and Practice, vol. 40, no. 2: $237-$ 247

Carlsson, B., Braunerhjelm, P., McKelvey, M., Olofsson, C., Persson, L. \& Ylinenpaa, H. (2013) "The evolving domain of entrepreneurship research", Small Business Economics, vol. 41, no. 4: 913-930

Carlsson, B., Braunerhjelm, P., McKelvey, M., Olofsson, C., Persson, L. \& Ylinenpaa, H. (2013) "The evolving domain of entrepreneurship research", Small Business Economics, vol. 41, no. 4: 913-930

Drucker, P.F. (2007) Innovation and Entrepreneurship: Practice and Principles. Oxford: Butterworth-Heinemann.

Fiet, J.O. (2001) "The theoretical side of teaching entrepreneurship", Journal of Business Venturing, vol. 16, no. 1: 1-24

Filip, P. (2017) "Development of individual entrepreneurship in Poland under crisis conditions", Analele Universităţii Ovidius Seria Științe Economice, vol. 17, no. 1: 484490

Hisrich, R.D., \& Peters, M.P. (1992) Entrepreneurship: Starting, Developing, and Managing a New Enterprise. Second Edition. Homewood, IL: Irwin.

Iazzolino, G., Coniglio, I.M., Verteramo, S. \& Giglio, C. (2019) "University students and entrepreneurship: An empirical analysis on Italian Universities", Journal of Entrepreneurship Education, vol. 22, no.5: 1-16

Komsi Koranti, 2013, Analisis Pengaruh Faktor Eksternal Dan Internal Terhadap Minat Berwirausaha, Proceeding PESAT (Psikologi, Ekonomi, Sastra, Arsitektur \& Teknik Sipil) Vol. 5 Oktober 2013

Kumar, S., Vifenda, A.T. \& Brigitta, M. (2013) „Students' Willingness to Become an Entrepreneur: A Survey of Non-Business Students of President University", IOSR Journal of Business and Management, vol. 15, no. 2: $94-102$
Lin, F., Moriano, J.A. \& Zarnowska, A. (2008) Teaching psychology of entrepreneurship: Perspective from six European, 1st Ed: Impreso en Espana

Manea, Cristina Lidia, Elena-Mirela Nichita \& Alina Milhalea Irimescu, 2019, "Determinants Of Entrepreneurship: An Examination Of Entrepreneurial Perception Of Students", Accounting and Management Information Systems Vol. 18, No. 4, pp. 588-613

Medar, L.I. (2015) "Entrepreneurship Education and The Economy Vicious Circles", Annals of the Constantin Brâncuşi University of Târgu Jiu, Economy Series, no. 1: 33 -36

Moberg, K., Vestergaard, L., Fayolle, A., Redford, D., Cooney, T., Singer, S., Sailer, K. \& Filip, D. (2014) „How to assess and evaluate the influence of entrepreneurship education: A report of the ASTEE project with a user guide to the tools", The ASTEE project - Assessment Tools and Indicators for Entrepreneurship Education"

Negoescu, G. \& Negoescu, L.G. (2013) "The Entrepreneurship, an Actual Challenge for the Young Graduates of Higher Education Institutions", Analele Universității Ovidius Seria Științe Economice, vol. 13, no. 1: 573578

Nicodim, L., Croitoru, G., \& Duica, M. (2016) "Quantitative investigation on the influence of social customer relationship management on the profitability of companies", "Ovidius" University Annals, Economic Sciences Series, vol. 16, 2nd issue: $367-$ 371 ;

Oosterbeek, H., Praag, v.M., \& Ijsselstein, A. (2010) „The impact of entrepreneurship education on entrepreneurship skill and motivation, Elseiver, vol. 54, no. 3:442-454 Ozaralli, N., \& Rivenburgh, N.K. (2016) „Entrepreneurial intention: antecedents to entrepreneurial behavior in the USA and Turkey", Journal of Global Entrepreneurship Research, vol. 6, no. 3:132

Rasmussen, E., Bulanova, O., Jensen, A. \& Causen, T. (2012) "The impact of sciencebased entrepreneurial firms: A literature review and policy synthesis", Norway: Nordlands Forskning-Nordland Research Institute

Stewart, W.H. Jr, Watson, W.E., Carland, J.C. and Carland, J.W. (1998), “A proclivity for 
entrepreneurship: a comparison of entrepreneurs, small business owners, and corporate managers", Journal of Business Venturing, Vol. 14 No. 2, pp. 189-214.

Sumedrea, S. (2017) "Fostering Entrepreneurial Culture in University", Bulletin of the Transilvania University of Braşov Series Economic Sciences, vol. 10, no. 1: 111-118

Susilaningsih, 2015, "Pendidikan Kewirausahaan Di Perguruan Tinggi:
Pentingkah Untuk Semua Profesi?", Jurnal Economia, Volume 11, Nomor 1

Tsakiridou, H. \& Stergiou, K. (2014) "Entrepreneurial Competences and Entrepreneurial Intentions of Students in Primary Education", International Journal of Humanities Social Sciences and Education (IJHSSE), vol. 1, no. 9:106-11 